\title{
PEMBUATAN SEDIAAN TEH CELUP DAUN SAGA (Abrus precatorius Linn) DAN DAUN SIRIH (Piper betle ) UNTUK OBAT KUMUR
}

\author{
Sri Puspita ${ }^{*}$, Elih Sutisna Yanto ${ }^{2}$, Farhan ${ }^{3}$ \\ 1,2,3 Sekolah Tinggi Ilmu Kesehatan Holistik \\ *Korespondensi: Jl. Veteran No.272 Ciseureuh Purwakarta, Email: vittananda365@gmail.com
}

\begin{abstract}
ABSTRAK
Latar Belakang: Obat kumur yang beredar di pasaran masih banyak yang mengandung etanol yang berfungsi sebagai antiseptik, namun etanol pada obat kumur dapat membuat permukaan jaringan lunak mulut (mukosa) menjadi kering serta rasa pedas berlebih pada obat kumur, sehingga obat kumur yang tidak mengandung etanol justru lebih popular.

Tujuan Penelitian: Penelitian ini bertujuan untuk membuat dan menguji stabilitas sediaan teh celup dari daun saga (Abrus precatorius Linn)dan daun sirih (Piper betle )untuk obat kumurdengan melakukan uji organoleptik selama tiga minggu.

Metode: Metode penelitian yang digunakan yaitu penelitian tindakan dengan instrumen penelitian menggunakan lembar pengamatan. Penelitian dilakukan dengan cara membuat simplisia dari daun saga dan daun sirih lalu dibuat sediaan. Susut pengeringan daun saga adalah $4,40 \%$ sedangkan daun sirih adalah $4,37 \%$. Formula sediaan yang dibuat berdasarkan perbandingan 50:50. Penelitian dilakukan dengan cara perlakuan penyimpanan sediaan pada suhu yang berbeda yaitu suhu kamar dan suhu sejuk. Pengujian stabilitas sediaan dengan pengamatan organoleptik, yaitu warna, bau, rasa dan bentuk.

Hasil: Hasil menunjukan bahwa sediaan yang disimpan pada suhu kamar dan suhu sejuk relatif stabil, karena dapat bertahan lebih dari tiga minggu tanpa ada perubahan dalam warna, rasa dan bentuk. Hasil pada penyimpanan suhu kamar didapatkan bau khas daun sirih kuat, sedangkan pada penyimpanan suhu kamar didapatkan bau khas daun sirih lemah.

Simpulan: Stabilitas sediaan yang baik adalah sediaan yang disimpan pada suhu sejuk, karena sediaan tidak mengalami perubahan yang signifikan baik itu rasa, warna, bau, dan bentuk sediaan.
\end{abstract}

Kata kunci: daun saga (Abrus precatorius Linn), daun sirih (Piper betle ), teh celup, uji organoleptik

\begin{abstract}
Background: Mouthwash on the market still contains a lot of ethanol which functions as an antiseptic, but ethanol in mouthwash can make the surface of the soft tissue of the mouth (mucosa) become dry and excessively spicy taste in mouthwash, so mouthwash that does not contain ethanol is even more popular.

Objective: This study aims to make and test the stability of tea bags from saga leaves (Abrus precatorius Linn) and betel leaf (Piper betle) for mouthwash by organoleptic test for three weeks.

Method: The research method used is action research with research instruments using observation sheets. The research was carried out by making simplicia from saga leaves and betel leaves and making preparations. The drying loss of saga leaves is $4.40 \%$ while betel leaves are $4.37 \%$. The dosage formula is made based on a 50:50 comparison. The research was carried out by means of storage preparation of different temperatures at room temperature and cool temperatures. Stability testing by organoleptic observation, namely color, smell, taste and shape.

Result: The results show that preparations stored at room temperature and cool temperatures are relatively stable, because they can last more than three weeks without any changes in color, taste and shape. The results of the room temperature storage obtained a distinctive smell of strong betel leaves, while at room temperature storage it was found that the characteristic odor of betel leaves was weak.
\end{abstract}

Conclusion: Good stock stability is the preparation stored at cool temperatures, because the preparation does not experience significant changes in taste, color, smell, and dosage form. 
Keywords: saga leaf (Abrus Precatorius Linn), betel leaf (Piper Betle Linn), tea bag, organoleptic test

\section{PENDAHULUAN}

Penggunaan obat kumur di Indonesia masih ada yang mengandung etanol. Etanol sebagai zat pelarut dalam obat kumur yang terbukti menimbulkan beberapa efek yang tidak diperlukan seperti sensasi terbakar ketika berkontak dengan lapisan kulit dalam mulut dan rasa kering pada mulut. ${ }^{1}$ Obat kumur yang beredar di pasaran masih banyak yang mengandung etanol yang berfungsi sebagai antiseptik, namun etanol pada obat kumur dapat membuat permukaan jaringan lunak mulut (mukosa) menjadi kering serta rasa pedas berlebih pada obat kumur, sehingga obat kumur yang tidak mengandung etanol justru lebih popular. ${ }^{2}$ Kesehatan mulut adalah suatu hal penting bagi manusia terutama dalam pergaulan sehari-hari. Berbagai masalah yang berhubungan dengan mulut sering terjadi dalam kehidupan manusia, diantaranya adalah bau mulut dan periodontal yang disebabkan oleh plak gigi. salah satu cara untuk mengatasi plak gigi yaitu dengan menggunakan obat kumur yang mengandung bahan anti bakteri. ${ }^{3}$ Daun saga merupakan salah satu tanaman yang dapat dimanfaatkan sebagai obat tradisional. Tanaman ini berkhasiat sebagai obat sariawan, obat batuk dan obat radang tenggorokan. ${ }^{4}$ Selain daun saga, ternyata dauh sirih memiliki khasiat untuk kesehatan mulut, Nugroho (2003) menyatakan bahwa Daun sirih dikenal sebagai bahan untuk menginang yang berguna untuk menguatkan gigi, menyembuhkan sariawan, menghilangkan bau mulut, dan menghentikan pendarahan gusi. Penggunaan daun sirih sebagai obat mempunyai dasar kuat karena adanya kandungan minyak atsiri yang merupakan komponen fenol alami yang dapat berfungsi sebagai antiseptik yang kuat. Salah satu kandungan fenol daun sirih adalah katekin. Senyawa ini bersifat bakterisidal dan menghambat proses glikosasi oleh bakteri keriogenik penghasil glukan yang dapat mengurangi pembentukan plak gigi. Keduanya memiliki khasiat untuk kesehatan mulut. Berdasarkan uraian mengenai manfaat dan kandungan dari daun saga dan daun sirih di atas, dan belum banyak peneliti yang mengembangkan obat kumur dari bahan alam daun saga (Abrus precatorius Linn) dan daun sirih (Piper betle), maka dari itu peneliti tertarik untuk membuat sediaan teh celup yang berfungsi sebagai obat kumur dari daun saga dan daun sirih untuk perawatan kesehatan mulut.

\section{METODE PENELITIAN}

Metode ini merupakan metode penelitian tindakan, yang dilaksanakan pada bulan Agustus Tahun 2018 di Laboratorium farmasi, Sekolah Tinggi Kesehatan Holistik Purwakarta.

\section{ALAT DAN BAHAN}

Peralatan yang digunakan pada penelitian ini yaitu Blender, Timbangan analitik, Sendok Tanduk, Pot salep kecil, Baskom, Oven, Sarung tangan, Kantong teh celup, Masker, Beaker Gelas, Gunting, Wadah plastik transparan, Kertas Perkamen, Nampan Bambu.

\section{CARA KERJA}

Pembuatan sediaan teh celup daun saga dan daun sirih diawali dengan penyortiran dan pencucian, daun saga dan daun sirih dicuci bersih lalu ditiriskan kemudian dihamparkan di ruangan pada suhu $30^{\circ} \mathrm{C}$ agar layu selama 1.5 jam. Kemudian dikeringkan dan di oven pada suhu $55^{\circ} \mathrm{C}$ selama 2 jam setelah daun saga dan daun sirih kering kemudian dihaluskan. Daun saga dan daun sirih dicampur dengan jumlah formulasi yang sudah ditentukan. Selanjutnya campuran daun saga dan daun sirih ditimbang lalu dimasukan ke dalam kemasan teh celup. Tiap kantong beratnya 2 gram. Terdiri dari daun saga 1 gram dan daun sirih 1 gram. Teh celup yang sudah jadi dimasukan ke dalam wadah tertutup baik. 


\section{HASIL PENELITIAN}

Hasil penelitian pembuatan teh celup yang terdiri dari daun saga dan daun sirih dilihat pada Tabel 1

Tabel 1. Data Simplisia

\begin{tabular}{|c|c|c|c|}
\hline Bahan & Berat Segar & Berat Kering & Kadar Susut Pengering \\
\hline Daun Saga & 571 gram & 86,87 gram & $4,40 \%$ \\
\hline Daun Sirih & 870 gram & 127,2 gram & $4,37 \%$ \\
\hline
\end{tabular}

Daun saga dan daun sirih dikeringkan dalam oven pada suhu $55^{\circ} \mathrm{C}$ selama 2 jam. Hasil pengeringan daun saga segar sebanyak 571 gram, didapatkan daun saga kering sebanyak 86,87 gram. Sedangkan dari daun sirih segar sebanyak 870 gram, didapatkan daun sirih kering sebanyak 127,2 gram.

Tabel 2. Hasil perhitungan susut pengeringan simplisia daun Saga

\begin{tabular}{|c|c|}
\hline Sampel Simplisia Daun Saga & Hasil \\
\hline Sampel A (5 gram) & $4,40 \%$ \\
\hline Sampel B (5 gram) & $4,38 \%$ \\
\hline Sampel C (5 gram) & $4,44 \%$ \\
\hline Rata - rata & $4,40 \%$ \\
\hline
\end{tabular}

Dilakukan susut pengeringan yaitu simplisia dibagi menjadi 3 (Tiga) sampel, masing-masing sampel beratnya sebanyak 5 gram kemudian dilakukan pengovenan dengan suhu $105^{\circ} \mathrm{C}$ selama 1 jam, kemudian didinginkan selama 30 menit. Hal ini dilakukan sebanyak 3 (tiga) kali pengulangan hingga diperoleh kadar susut pengering daun saga adalah $4,40 \%$.

Tabel 3. Hasil perhitungan susut pengeringan simplisia daun Sirih

\begin{tabular}{|c|c|}
\hline Sampel Simplisia Daun Sirih & Hasil \\
\hline Sampel A (5 gram) & $4,31 \%$ \\
\hline Sampel B (5 gram) & $4,39 \%$ \\
\hline Sampel C (5 gram) & $4,42 \%$ \\
\hline Rata - rata & $4,37 \%$ \\
\hline
\end{tabular}

Hasil perhitungan susut pengeringan yaitu simplisia dibagi menjadi 3 (Tiga) sampel, masing-masing sampel beratnya sebanyak 5 gram kemudian dilakukan pengovenan dengan suhu $105^{\circ} \mathrm{C}$ selama 1 jam, kemudian didinginkan selama 30 menit. Hal ini dilakukan sebanyak 3 (tiga) kali pengulangan hingga diperoleh kadar susut pengering daun sirih adalah 4,37\%. Data tersebut menunjukan bahan yang digunakan memenuhi persyaratan simplisia yang baik yaitu persentase kadar air kurang dari $10 \%$.

\section{HASIL UJI ORGANOLEPTIK}

Stabilitas sediaan teh celup yang terdiri dari daun saga dan daun sirih setelah melalui uji organoleptis selama tiga minggu (21) hari, menunjukan sediaan yang stabil selama penyimpanan dalam wadah tertutup baik pada suhu kamar $\left(25^{\circ} \mathrm{C}\right)$ dan suhu sejuk $\left(8^{\circ} \mathrm{C}\right)$ baik dari rasa, warna, bau, dan bentuk sediaan, dari kedua jenis sediaan teh celup yang terdiri dari daun saga dan daun sirih memiliki perbedan dari aroma, yaitu Sediaan teh celup pada penyimpanan suhu kamar $25^{\circ} \mathrm{C}$ menghasilkan bau khas daun sirih yang kuat, sedangkan stabilitas sediaan teh celup pada penyimpanan suhu sejuk $8^{\circ} \mathrm{C}$ menghasilkan bau khas daun sirih lemah.

\section{PEMBAHASAN PENELITIAN}

Daun saga dan daun sirih dicuci dan dikeringkan. Pembuatan daun saga dan daun sirih kering dilakukan dengan metode pengovenan pada suhu $55^{\circ} \mathrm{C}$ selama 2 jam. Setelah dilakukannya pengovenan sehingga daun saga dan daun sirih menjadi simplisia, 
kemudian masing-masing daun saga dan daun sirih dimasukan kedalam klip yang tertutup rapat, hal ini bertujuan untuk menjaga kebersihan simplisia sehingga layak untuk digunakan. Pengujian organoleptis sediaan selama 3 minggu, dengan tujuan untuk menguji kestabilan sediaan dan memastikan tidak terjadinya perubahan warna, bau, rasa, dan bentuk. Pengujian dilakukan dengan menyimpan sediaan dalam dua tempat yang berbeda, yaitu pada suhu kamar $\left(25^{\circ} \mathrm{C}\right)$ dan suhu sejuk $\left(8^{\circ} \mathrm{C}\right)$, sepuluh sampel uji ini tidak menunjukan perubahan yang signifikan dari bentuk, warna, bau maupun rasa.

Dari bentuk, warna dan rasa masih sama tidak ada perubahan, namun bau/ Aroma dari sepuluh sampel menunjukan perubahan yang berbeda, diantaranya adalah 5 (lima) sampel yang disimpan pada suhu sejuk menunjukan tidak adanya aroma dari daun sirih, sehingga sediaan bau khas daun sirih lemah. Sedangkan sediaan yang disimpan pada suhu kamar memiliki bhau khas daun sirih kuat, hal ini karena minyak atsiri yang terkandung di dalam daun sirih mudah menguap pada suhu kamar. Maka dari hasil pengujian sediaan dapat disimpulkan bahwa sediaan teh celup ini setelah 3 (tiga) minggu masih stabil dan dapat digunakan sebagai teh celup untuk obat kumur untuk menjaga kesehatan mulut.

\section{SIMPULAN}

Berdasarkan pengujian organoleptis yang telah dilakukan selama 21 hari, Stabilitas Sediaan teh celup pada penyimpanan suhu kamar $25^{\circ} \mathrm{C}$ adalah menghasilkan warna hijau pucat, rasa hambar, berbentuk serbuk kasar dan bau khas daun sirih kuat, sedangkan stabilitas sediaan teh celup pada penyimpanan suhu sejuk $8^{\circ} \mathrm{C}$ menghasilkan warna hijau pucat, rasa hambar, berbentuk serbuk kasar dan bau khas daun sirih lemah. Stabilitas sediaan yang baik adalah sediaan yang disimpan pada suhu sejuk, karena sediaan tidak mengalami perubahan yang signifikan baik itu rasa, warna, bau, dan bentuk sediaan. Kedua sediaan teh celup stabil dan mampu bertahan lebih dari 21 hari.

\section{DAFTAR PUSTAKA}

1. Epstein, 2008.Burket's Oral Medicine 11thed.Ontario:Elsevier

2. Liliana. 2009. Pengaruh tween 80 sebagai surfaktan terhadap efektifitas daya antibakteri minyak cengkeh dalam sediaan obat kumur. Widya mandala catholic University. Surabaya.

3. Pradewa, m. R. (2008). Formulasi sediaan obat kumur berbahan dasar gambir (uncaria gambier roxb).

4. Syamsulhidayat, Hutapea. Inventaris Tanaman Obat Indonesia. Jakarta : Departemen Kesehatan Republik Indonesia; 1991. 